\title{
Selected risk factors of infertility in women: case control study
}

\author{
Mallikarjuna M. ${ }^{*}$, Rajeshwari B. . $^{2}$

\begin{abstract}
${ }^{1}$ Department of Obstetrics \& Gynaecology, Kerala Medical College, Mangode, Palakkad, Kerala, India
\end{abstract} \\ ${ }^{2}$ Department of Obstetrics \& Gynaecology, Kamineni Institute of Medical Sciences, Narketpally, Nalgonda, \\ Telangana, India
}

Received: 13 October 2015

Accepted: 28 October 2015

\author{
*Correspondence: \\ Dr. Mallikarjuna M, \\ E-mail: ramspam@gmail.com
}

Copyright: (c) the author(s), publisher and licensee Medip Academy. This is an open-access article distributed under the terms of the Creative Commons Attribution Non-Commercial License, which permits unrestricted non-commercial use, distribution, and reproduction in any medium, provided the original work is properly cited.

\begin{abstract}
Background: Infertility implies apparent failure of a couple to conceive. If a couple fails to achieve pregnancy after one year of unprotected intercourse, it is an indication to investigate the couple. This is based on the observation that, $80 \%$ of the normal couples achieve conception within a year.

Methods: A case control study on the selected risk factors of female infertility among fifty females attending the Tertiary care centre was conducted. The data was collected from fifty cases and fifty controls, matched for age, using a pre-structured questionnaire. The data collected included menstrual details, uterine or ovarian disorders, genitourinary infections, systemic illness, hyperprolactinemia and weight gain. Data was analysed to find out risk factors and its association using Odds ratio, chi-square and logistic regression.

Results: The factors include age, duration of menstrual cycles, dysmenorrhea, Hyperprolactinemia, recent weight gain, body mass index (BMI), ovarian dysfunctions, thyroid disorders and uterine abnormalities.

Conclusions: Early screening and diagnosis of menstrual disorders and diseases like hyperprolactinemia, Thyroid disorders, uterine abnormalities, ovarian dysfunctions and correcting them by appropriate treatment.
\end{abstract}

Keywords: Infertility, Risk factors, Women

\section{INTRODUCTION}

Infertility is defined as failure to conceive after one year of regular unprotected sexual relationship. ${ }^{1}$ Infertility classified as primary, when there is no history of pregnancy having occurred, or secondary, when inability to conceive occurs after one or more successful pregnancies. $^{2}$

Female infertility is a growing problem in the present scenario due to several reasons. Many of the childless couples suffer a lot of mental and emotional problems. Even though majority of cases go unexplained, a good number of cases could be attributed to female infertility. It leads to a lot of economic burden to families and societies. A marriage becomes successful when the couples reproduce their young ones. Failure of this often leads to unhappy married lives and divorces.

Infertility in a couple can be due to problems in either women or men, not necessarily both. roughly it is estimated that $1 / 3^{\text {rd }}$ of the time fertility problems lie with the man, $1 / 3^{\text {rd }}$ of the time with women and $1 / 3^{\text {rd }}$ of the time with both men and women.

Infertility is termed primary if conception has never occurred; secondary infertility means the patient fails to conceive after having achieved a previous conception. Optimal age for conception is 20-35 years in women. Over the age of 40 years reduces the fertility rate as well as increases the risk of chromosomally and other malformed fetus. Both partners contribute varyingly to 
the occurrence of the infertile state. Hence the couple should be counselled individually and then together.

Infertility is growing at an alarming pace, especially in the cities according to a survey conducted by an International Institute of Population Sciences. Out of 250 million individuals estimated to be attempting parenthood at any given time, 13 to 19 million couples are likely to be infertile. Nearly 30 million couples in the country suffer from infertility, making the incidence rate $10 \%$. Infertility is a worldwide health problem with one in six couples suffering from this condition and with a major economic burden on the global healthcare industry. ${ }^{3}$ Today, infertility is no longer recognized as only a female problem. In fact, the term infertility is a broad term, often loosely used. It actually refers to a range of disorders some of which affect the male, and some the female, and contribute to childlessness in a couple. In female, polycystic ovary disease (PCOD), genital tuberculosis, fallopian tube defects, blockage of tube, endometriosis, obesity, use of certain medication, and smoking and alcohol consumption may contribute to the conception problems. Globally, every year 60-80 million couples suffer from infertility as estimated of which India alone is probably between $15-20$ million (25\%). Thus this review will focus on finding causes that may lead to infertility. ${ }^{4}$

With the advent of newer habits, there is increased risk among females for their fertility to get reduced. Early intervention of these risk factors will bring down the incidence of infertility. There are many causes of female infertility some of which are bypassed by medical intervention.

\section{METHODS}

\section{Study design}

Case control study

\section{Study setting}

Tertiary care centre, Karnataka

\section{Study subject}

Cases: Fifty women who have not conceived even after one year of cohabitation, seeking treatment at infertility clinic considering primary infertility only.

Controls: Fifty women who have conceived within one year of cohabitation \& admitted in Gynecology wards.

\section{Exclusion criteria}

Secondary infertility cases-women who are infertile after first pregnancy (including ectopic pregnancy, abortion). Women who had conceived after infertility treatment (in taking control). Those with male partners having reduced infertility (diagnosed).

\section{Uncooperative patients}

Sample: 50 cases \& 50 controls were taken. All new cases of primary infertility attending Infertility clinic will be taken as cases. Age matched controls will be taken from those admitted in Gynecology wards.

\section{Ethical consideration}

Institutional ethical clearance was obtained and consent was taken from the study subjects. Confidentiality of individual data was maintained.

\section{Data collection}

Data were collected by direct interview method using a semi structured questionnaire. Their case records were also referred.

\section{Analysis of data}

Data was entered and analysed to find out risk factors and its association using Odds ratio, chi-square and logistic regression.

\section{RESULTS}

Table 1: Distribution of age.

\begin{tabular}{|llll|}
\hline \multirow{2}{*}{ Age } & \multicolumn{2}{l}{ Disease Status } & Total \\
& Case & Control & \\
\hline$>30$ & $20(20 \%)$ & $21(21 \%)$ & $41(41 \%)$ \\
\hline$<30$ & $30(30 \%)$ & $29(29 \%)$ & $59(59 \%)$ \\
\hline Total & 50 & 50 & 100 \\
\hline
\end{tabular}

P-value: 0.83

From the study, it was found that age has no significance in female infertility (Table 1).

Table 2: Case control study of educational status \& infertility.

\begin{tabular}{|llll|}
\hline $\begin{array}{l}\text { Educational } \\
\text { status }\end{array}$ & \multicolumn{2}{l}{ Disease status } & Total \\
\hline Lower than SSLC & $10(10 \%)$ & $8(8 \%)$ & $18(18 \%)$ \\
\hline Higher than SSLC & $40(40 \%)$ & $42(42 \%)$ & $82(82 \%)$ \\
\hline Total & 50 & 50 & 100 \\
\hline
\end{tabular}

P-value: 0.603

From the study it was found that, the relation between educational status and female infertility is insignificant (Table 2).

From the study it was found that, the association between duration of menstrual cycle and infertility is significant and women with duration of menstrual cycle $>35$ days have 3.632 times higher risk of becoming infertile than others (Table 3 ). 
Table 3: Case control study of duration of menstrual cycle \& infertility.

\begin{tabular}{|llll|}
\hline $\begin{array}{l}\text { Duration of } \\
\text { Menstrual Cycle }\end{array}$ & \multicolumn{2}{l}{ Disease status } & Total \\
\hline$>35$ days & case & control & \\
\hline$<35$ days & $12(12 \%)$ & $4(4 \%)$ & $16(16 \%)$ \\
\hline Total & $38(38 \%)$ & $46(46 \%)$ & $84(84 \%)$ \\
\hline P-val 0 & 50 & 50 & 100 \\
\hline
\end{tabular}

P-value: 0.02

Table 4: Case control study of age of menarche \& infertility.

\begin{tabular}{|llll|}
\hline \multirow{2}{*}{ Age of menarche } & \multicolumn{2}{l|}{ Disease status } & Total \\
\hline$>15$ years & case & control & \\
\hline$<15$ years & $2(2 \%)$ & $2(2 \%)$ & $4(4 \%)$ \\
\hline Total & $48(48 \%)$ & $48(48 \%)$ & $96(96 \%)$ \\
\hline
\end{tabular}

P-value: 1

From the study it was found that, the relation between age of menarche and female infertility is insignificant (Table 4).

Table 5: Case control study of irregularity of menstrual cycles \& infertility.

\begin{tabular}{|llll|}
\hline \multirow{2}{*}{ Menstrual cycles } & \multicolumn{2}{l}{ Disease status } & Total \\
\hline irregular & case & control & \\
\hline regular & $15(15 \%)$ & $10(10 \%)$ & $25(25 \%)$ \\
\hline Total & $35(35 \%)$ & $40(40 \%)$ & $75(75 \%)$ \\
\hline
\end{tabular}

P-value: 0.248

From the study it was found that, the association between irregularity of the menstrual cycles and infertility is insignificant (Table 5).

Table 6: Case control study of dysmenorrhea \& infertility.

\begin{tabular}{|llll|}
\hline \multirow{2}{*}{ Dysmenorrhea } & \multicolumn{2}{l}{ Disease status } & Total \\
\hline yes & case & control & \\
\hline no & $9(9 \%)$ & $21(21 \%)$ & $30(30 \%)$ \\
\hline Total & $41(41 \%)$ & $29(29 \%)$ & $70(70 \%)$ \\
\hline
\end{tabular}

P-value: 0.009

From the study it was found that, there is a significant association between dysmenorrhea and fertility. This may be explained by the fact that dysmenorrhea is associated to ovulatory cycles, which are needed for fertilization (Table 6).

From the study it was found that, the association between no. of menstrual flow days and infertility is insignificant (Table 7).
From the study it was found that, the association between intermenstrual bleeding and infertility is insignificant (Table 8).

Table 7: Case control study of no. of menstrual flow days \& infertility.

\begin{tabular}{|llll|}
\hline $\begin{array}{l}\text { No. of menstrual } \\
\text { flow days }\end{array}$ & \multicolumn{2}{l}{ Disease status } & Total \\
\hline$<3$ days & case & control & \\
\hline$>3$ days & $9(9 \%)$ & $8(8 \%)$ & $17(17 \%)$ \\
\hline Total & $41(41 \%)$ & $42(42 \%)$ & $83(83 \%)$ \\
\hline
\end{tabular}

P-value: 0.790

Table 8: Case control study of intermenstrual bleeding \& infertility.

\begin{tabular}{|lll|l|}
\hline $\begin{array}{l}\text { Intermenstrual } \\
\text { bleeding }\end{array}$ & \multicolumn{2}{l|}{ Disease status } & Total \\
\hline yes & case & control & \\
\hline no & $2(2 \%)$ & $1(1 \%)$ & $3(3 \%)$ \\
\hline Total & $48(48 \%)$ & $49(49 \%)$ & $97(97 \%)$ \\
\hline
\end{tabular}

P-value: 0.558

Table 9: Case control study of hyperprolactinemia \& infertility.

\begin{tabular}{|llll|}
\multirow{2}{*}{ Hyperprolactinemia } & \multicolumn{2}{l}{ Disease status } & \multirow{2}{*}{ Total } \\
\cline { 1 - 3 } yes & case & control & \\
yo & $12(12 \%)$ & $2(2 \%)$ & $14(14 \%)$ \\
\hline Total & $38(38 \%)$ & $48(48 \%)$ & $86(86 \%)$ \\
\hline
\end{tabular}

P-value: 0.004

From the study, it was found that Hyperprolactinemia is a significant risk factor contributing to infertility and women with Hyperprolactinemia have 7.579 times higher risk of infertility than others (Table 9).

Table 10: Case control study of recent weight gain \& infertility.

\begin{tabular}{|llll|}
\hline \multirow{2}{*}{ Recent weight gain } & \multicolumn{2}{l}{ Disease status } & \multirow{2}{*}{ Total } \\
\cline { 1 - 3 } & case & control & \multirow{2}{*}{ 13(13\%) } \\
\hline yes & $11(11 \%)$ & $2(2 \%)$ & $13(1 \%)$ \\
\hline no & $39(39 \%)$ & $48(48 \%)$ & $87(87 \%)$ \\
\hline Total & 50 & 50 & 100 \\
\hline
\end{tabular}

From the study it was found that, recent weight gain in women is a significant risk factor associated with infertility and women with recent weight gain have 6.769 times higher risk of infertility than others (Table 10).

From the study it was found that, the association between Duration of cohabitation and female infertility is insignificant (Table 11). 
From the study it was found that, the association between the knowledge of fertile period and female infertility is insignificant (Table 12).

Table 11: Case control study of duration of cohabitation \& infertility.

\begin{tabular}{|llll|}
\hline $\begin{array}{l}\text { Duration of } \\
\text { cohabitation }\end{array}$ & \multicolumn{2}{l}{ Disease status } & Total \\
\hline$>3$ years & case & control & \\
\hline $1-3$ years & $18(18 \%)$ & $16(16 \%)$ & $34(34 \%)$ \\
\hline Total & $32(32 \%)$ & $34(34 \%)$ & $66(66 \%)$ \\
\hline
\end{tabular}

P-value: 0.673

Table 12: Case control study of knowledge of fertile period \& infertility.

\begin{tabular}{|llll|}
\hline Knowledge of fertile & \multicolumn{2}{l}{ Disease status } & Total \\
\cline { 2 - 4 } period & case & control & \\
\hline no & $13(13 \%)$ & $12(12 \%)$ & $25(25 \%)$ \\
\hline yes & $37(37 \%)$ & $38(38 \%)$ & $75(75 \%)$ \\
\hline Total & 50 & 50 & 100 \\
\hline
\end{tabular}

P-value: 0.817

Table 13: Case control study of BMI \& infertility.

\begin{tabular}{|llll|}
\hline \multirow{2}{*}{ BMI $(\mathrm{kg} / \mathrm{m} 2)$} & \multicolumn{2}{l}{ Disease status } & Total \\
\hline$>25$ & case & control & \\
\hline$<25$ & $21(21 \%)$ & $8(8 \%)$ & $29(29 \%)$ \\
\hline Total & $29(29 \%)$ & $42(42 \%)$ & $71(71 \%)$ \\
\hline
\end{tabular}

P-value: 0.004

From the study, it was found that, BMI $>25 \mathrm{~kg} / \mathrm{m} 2$ (overweight) is a significant risk factor contributing to infertility and women with overweight have 3.802 times higher risk for becoming infertile than others (Table 13).

Table 14: Case control study of ovarian dysfunctions \& infertility.

\begin{tabular}{|llll|}
\hline $\begin{array}{l}\text { Ovarian } \\
\text { dysfunctions }\end{array}$ & \multicolumn{2}{l}{ Disease status } & Total \\
\hline$>25$ & case & control & \\
\hline$<25$ & $21(21 \%)$ & $8(8 \%)$ & $29(29 \%)$ \\
\hline Total & $29(29 \%)$ & $42(42 \%)$ & $71(71 \%)$ \\
\hline
\end{tabular}

P-value: 0.00

The proportion of women who are known patients of ovarian dysfunctions is more among cases (16\%) as compared to controls (1\%). From the study it was found that, the association between ovarian dysfunctions and female infertility is significant and women with ovarian dysfunctions have 23.059 times higher risk for becoming infertile than others (Table 14).
Table 15: Case control study of thyroid disorders \& infertility.

\begin{tabular}{|c|c|c|c|}
\hline \multirow{2}{*}{$\begin{array}{l}\text { Thyroid } \\
\text { disorders }\end{array}$} & \multicolumn{2}{|c|}{ Disease status } & \multirow{2}{*}{ Total } \\
\hline & case & control & \\
\hline yes & $15(15 \%)$ & $2(2 \%)$ & $17(17 \%)$ \\
\hline no & $35(35 \%)$ & $48(48 \%)$ & $83(83 \%)$ \\
\hline Total & 50 & 50 & 100 \\
\hline
\end{tabular}

P-value: 0.001

The proportion of women who are known patients of Thyroid disorders are more among cases (15\%) than among controls $(2 \%)$.

From the study, it was found that, Thyroid disorders form significant risk factors contributing to female infertility and women with thyroid disorders have 10.286 times higher risk for becoming infertile than others (Table 15).

\section{Binary logistic regression}

From the odds ratio obtained from analysis, all the factors with $\mathrm{p}$ value $\leq 0.05$ were taken for binary logistic regression. The factors include age, duration of menstrual cycles, dysmenorrhea, hyperprolactinemia, recent weight gain, body mass index (BMI), ovarian dysfunctions, thyroid disorders and uterine abnormalities.

Table 16: Crude and adjusted $p$ values and odds ratios.

\begin{tabular}{|lclll|}
\hline Risk factors & $\begin{array}{l}\text { Odds } \\
\text { ratio }\end{array}$ & $\begin{array}{l}\mathrm{p} \\
\text { value }\end{array}$ & $\begin{array}{l}\text { adjusted } \\
\text { odds } \\
\text { ratio }\end{array}$ & $\begin{array}{l}\text { adjusted } \\
\text { p value }\end{array}$ \\
\hline $\begin{array}{l}\text { Duration of } \\
\text { menstrual } \\
\text { cycles }\end{array}$ & 3.632 & 0.02 & 4.762 & 0.029 \\
\hline Dysmenorrhea & 0.303 & 0.009 & 6.0857 & 0.009 \\
\hline $\begin{array}{l}\text { Hyperprolacti } \\
\text { nemia }\end{array}$ & 7.579 & 0.004 & 8.306 & 0.004 \\
\hline $\begin{array}{l}\text { Recent weight } \\
\text { gain }\end{array}$ & 6.769 & 0.007 & 7.162 & 0.007 \\
\hline BMI & 3.802 & 0.004 & 8.208 & 0.004 \\
\hline $\begin{array}{l}\text { Ovarian } \\
\text { dysfunctions }\end{array}$ & 23.059 & 0.00 & 15.946 & 0.000 \\
\hline $\begin{array}{l}\text { Thyroid } \\
\text { disorders }\end{array}$ & 10.286 & 0.001 & 11.977 & 0.001 \\
\hline $\begin{array}{l}\text { Uterine } \\
\text { abnormalities }\end{array}$ & 16.00 & 0.00 & 18.881 & 0.00 \\
\hline
\end{tabular}




\section{DISCUSSION}

Demographic characteristic of the study subjects is one of the factors affecting fertility. The present study showed that the majority of cases with primary infertility were from rural areas, followed by urban areas. Females lived in rural areas were more likely to develop infertility relative to those living in urban areas. While William, et al in their study reported that, prevalence of primary infertility in rural areas was high, low in urban areas and similar prevalence in suburban areas. ${ }^{5}$ In accordance to the present study, Valdes, et al in their study, revealed that females with age of menarche more than 16 years were more risky to develop infertility than those with age of menarche less than 16 years. ${ }^{6}$ It was found also in the present study that age of marriage was a significant predictor for primary infertility. This result was in agreement with two studies conducted in USA and in Denmark. $^{7,8}$ Other risk factors proved in our study to be significant such as family history of infertility and menstrual cycle irregularities, as there is high association between them and the occurrence of primary infertility, and this is proved by two studies respectively, Melissa, et al reported that the incidence of infertility among women with positive family history of infertility among mothers and sisters were $24 \%$ and $32 \%$ respectively. ${ }^{9}$ Giwercman, et al found that many abnormal cycles may be associated with infertility and this association was significant. ${ }^{10}$ In the present study, there was significant association between history of previous surgical operations such as abdominal exploration and appendectomy and occurrence of infertility. In support of our findings, Regan, et al in their study reported that infertility may follow suppurative appendicitis, peritonitis of other causes or any abdominal surgery that causes a 5 fold increase in risk of infertility. ${ }^{11}$ Multiple gynaecological diseases such as endometriosis, polycystic ovary and uterine fibroid were reported to be associated with infertility which is consistent with the present study only in some items. Labbok, et al found that all stages of endometriosis were associated with infertility. ${ }^{12}$ Fujishita recently observed that pelvic endometriosis was usually associated with infertility. ${ }^{13}$ Mc Donald, et al and Franks found that women with PCOS were concomitant with increased risk of infertility and menstrual irregularities. ${ }^{14,15}$ In the present study there was significant association between PCOS as a risk factor and primary infertility as about one third of women with primary infertility had PCOS. Likewise, in the present study, there was significant association between STI as a risk factor for primary and secondary infertility irrespective of the type of STI and this association was proved in univariate and multivariate analysis with a considerable population attributable risk. In support of our findings, Blumer et al reported in their study that women with episodes of genital infection had a 10 fold risk of subsequent tubal infertility irrespective of the type of micro-organisms causing the infection. ${ }^{16}$ Recently ElShazly et al reported similar significant impact of Trichomonas vaginalis infection on infertile Egyptian females. ${ }^{17}$
Logistic regression analysis revealed in the current study that, the significant predictor factors include age, duration of menstrual cycles, dysmenorrhea, Hyperprolactinemia, recent weight gain, Body Mass Index (BMI), ovarian dysfunctions, thyroid disorders and uterine abnormalities Giwercman et al reported that significant risk factors for infertility among primary infertile females were: family history of infertility, women's age and history of previous operations, while genital infection is the only risk factor for secondary infertility. While Regan, et al found that the only risk factors of infertility in their subjects were: history of previous surgical operations and women's age. ${ }^{11}$ Valdes, et al suggested that the risk factors of infertility among primary infertile females were: age of menarche, women's age and history of previous surgical operations, while genital infection and PCOS were significant among secondary infertile females. ${ }^{18}$

\section{Funding: No funding sources}

Conflict of interest: None declared

Ethical approval: The study was approved by the Institutional Ethics Committee

\section{REFERENCES}

1. World Health Organization. Female infertility. Techn Report series. 1998:401.

2. Frank O. Worldwide infertility: Estimation and implications. Population development review. 1993;9:137-44.

3. Dutta DC. Textbook of Gynaecology. 5 th Edition. 2009:220.

4. Sharath KC, Najafi M, Malini SS. Association of Obesity with Male Infertility among Infertile Couples is not Significant in Mysore, South India. Advanced Studies in Biology. 2013;5:319-25.

5. Buckett B, Bentick B. The epidemiology of infertility in a rural population. Acta Obstet Gynecol Scand. 1997;76:233-7.

6. Booth M, Beral V. Treatment of PCOS. J Middle East Fertil Soc. 2000;5:120-5.

7. Ralph S, Rutherford A, Wilson J. Influence of bacterial vaginosis on conception and miscarriage among infertile women. BMJ. 1999;319:220-3.

8. Cornillie F, Oosterlynck D, Lauweryns J, Koninckx p. Population study of causes and risk factors of infertility. BMJ. 1995;291:1693-7.

9. David L. Alcohol reduces fertilization success. Lancet. 1994;18:276-9.

10. William B. Population study of the epidemiology of infertility. Acta Obstet Gynecol Scand. 1997;76:2337.

11. Regan L, Owen E, Jacobs H. Surgery and risk of infertility and miscarriages. Lancet. 1990;336:11414.

12. Giwercman A, Kretser D, Skakkebaek N. Risk factors of infertility. Lancet. 1994;343:1473-9.

13. Kennedy $H$. Infertility in women of advanced reproductive age. Am J Obst Gynecol. 1999;181:952-7. 
14. Mc Donald J, Mc Quinn B, Mc Clure N. Anovulatory polycystic ovarian syndrome. Fertil Steril. 1993;59:729-33.
15. Franks S. Polycystic Ovary Syndrome. N Engl J Med 1995;333:853-61.

Cite this article as: Mallikarjuna M, Rajeshwari BV. Selected risk factors of infertility in women: case control study. Int J Reprod Contracept Obstet Gynecol 2015;4:1714-9. 